\title{
Analysis Factor Related to the Quality of Physical Conditions Martial Art in Match Category (Empirical Studies of the Martial Arts adolescent Athlete)
}

\author{
Haris Nugroho \\ FKIP, Universitas Negeri Sebelas Maret Surakarta, Indonesia
}

\begin{abstract}
This study aimed to know: (1) Anthropometric factors that determine the physical quality of the martial arts athletes Competition category of martial arts Adolescent Athletes, (2) Physical condition factors that determine the physical quality of martial arts athletes of the match category. This study used correlational design, using confirmatory factor analysis techniques. Confirmatory factor analysis technique through SPSS program 23.00 with the provision if the measure of sampling adequacy (MSA>0.5) then the instrument is feasible to use and $(M S A<0.5)$ then the instrument is not feasible to use with significant level $\alpha=0.05$, for Confirm the latent variables that determine the physical quality of the martial arts athlete of the match category. The collected data is then verified and tabulated to then be quantitatively processed with : (a) Multivariate confirmatory factor analysis to reduce to several factors only and (b) Calculating the contribution value of each factor on the dominant latent variable is transformed in anti-image correlation and communalities.
\end{abstract}

Keywords: Analysis Factor, Physical condition, martial arts, match category

\section{Introduction}

The development of Indonesia's martial arts sport has ups and downs of achievement. It can be seen from several multi-event and world championship followed by Indonesia. Even for several times, Indonesia has failed to achieve maximum achievement, such as the 2002 world championships in Penang Malaysia, 2004 world championships in Singapore, 2007 world championship in Pahang Malaysia, and multi-event SEA Games in 2003 in Vietnam, SEA Games in 2005 in the Philippines and the 2009 SEA Games in Laos. The unmistakable evidence of
Indonesia's martial arts failure at some of the world championships and multi-event SEA Games will be a stark contrast when it comes to cultural, It is given that martial arts is a traditional sport native to the Indonesian nation so it is very reasonable if "should" Indonesia martial arts achievement can speak a lot and dominate at various international events. Furthermore, the researcher tries to analyze gold medal achievement that is processed from various sources in multi-event SEA Games and world championship as a clear picture of the ups and downs of Indonesia martial arts achievement as follows

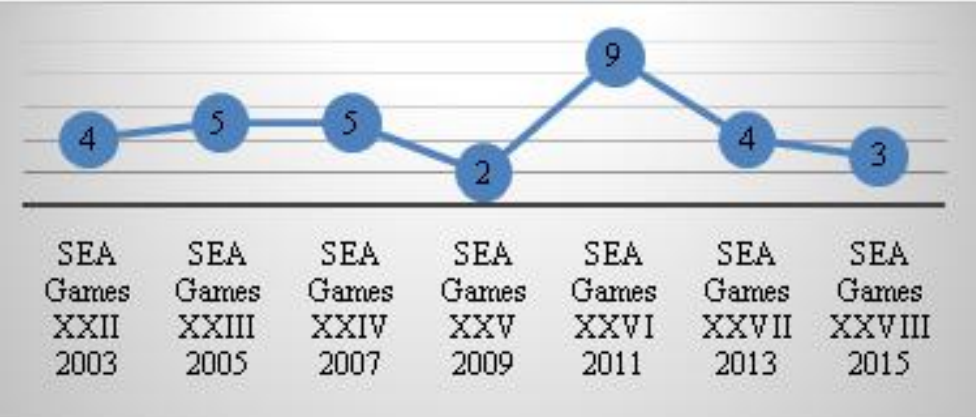

Chart 1.1: Obtaining Gold Medal Branch of Martial arts Sports on Multi Event SEA Games

Source : Processed

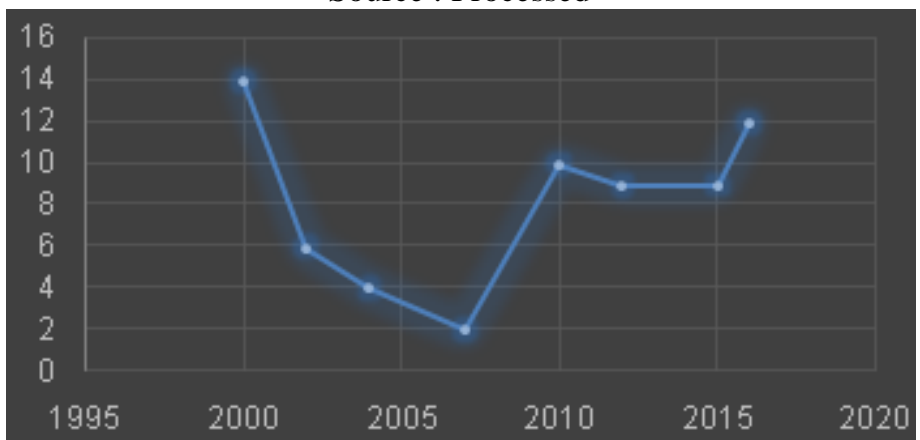

Charts 1.2: Obtaining Gold Medal Branch of Martial arts Sports At the World Championships

Volume 6 Issue 7, July 2017

www.ijsr.net

Licensed Under Creative Commons Attribution CC BY 


\section{International Journal of Science and Research (IJSR) \\ ISSN (Online): 2319-7064}

Index Copernicus Value (2015): 78.96 | Impact Factor (2015): 6.391

If examined more deeply to the results of Indonesian material art achievement in international championships both in the world championships and multi-event SEA Games, the achievement of the maximum shown single category, double and team, while for match category decreased achievement and failed to compete with Vietnam And Malaysia who became the heavy rivals of the state of Indonesia in every championship.

In order to develop the achievement of material art, a profile study of martial arts athletes is required. The folks' profile is needed as a foundation in reflecting the needs of athlete achievers, such as: physical, technical, tactical and mental. To find out the physical capability of a martial art it is necessary to study the study of the needs of the components of supporting physical conditions and statistical tests that can describe the profile of the sport of martial arts. However, until now there have been no empirical testing related components of physical conditions and anthropometry that best suits the physical needs of the sport of martial arts

\section{Theoretical Review}

\section{A. Martial arts in Competition Category}

In accordance with the Indonesian martial arts Game Rules munas IPSI 2012 results in Chapter I about Match Rules, especially on Article 1 The Definition of Each Category is mentioned that "Competition Category is: Category featuring 2 (two) fighter from different angles. Both face each other using the elements of defense and attack ie: Fending / dodging / attacking on target and dropping opponent; Using competing techniques and tactics, endurance of stamina and morale, using the rules by utilizing the wealth of techniques and stance (PB IPSI, 2012).

\section{B. Physical Conditions}

Physical condition is an important element and the basis for developing techniques, tactics, and strategies in various sports. According to Sajoto (1988), physical condition is one of the most indispensable requirements in improving the achievement of an athlete, even as the point of departure of a sporting prefix of achievement. Further explained that the physical condition is a unified whole of the components that can't be separated just like that, either upgrading or maintenance (Sajoto, 1988).

According Harsono components of physical conditions is cardiovascular endurance, strength resistance, muscle strength (strength), flexibility, speed, stamina, agility, power (Harsono, 1988). Another classification developed by Bouchard, presented by Sugiyanto shows a tendency, providing a more detailed description of the physical domain. The classification Bouchard makes, uses the term "physical qualities". The classifications made are as follows: (1) organic quality, consisting of aerobic capacity and anaerobic capacity; (2) Muscle quality, namely: muscle strength, aerobic capacity of local muscle, anaerobic capacity of local muscle, power, and flexibility; (3) Quality of kinetic perception, consisting of reaction speed, speed of movement, coordination of nerves, and kinetic sensitivity (Sugiyanto, 1993).

\section{Anthropometry}

The term of anthropometry comes from the word "anthropos (man)" which means man and "metron (measure)" which means size (Bridger, 2003). Wickens et al. (2004) explains that anthropometry is the study and measurement of the dimensions of the human body. According to Sanders and McCormick; Pheasant and Pulat that anthropometry is the measurement of body dimensions or other physical body characteristics that are relevant to the design of something that people wear. (Sanders and McCormick, 1987; Pheasant, 1988; Pulat, 1992). In general anthropometric measurements can be divided into two types: static anthropometric and dynamic anthropometric measurements (Tarwaka, 2004). In this paper only presented the type of static anthropometric measurement.

\section{Analysis of Movement Type and Physical Elements of Martial Art Athlete}

The basic techniques of attack in the sport of pencak silat can be briefly reviewed based on the characteristics of movement, the physical elements involved, and the major muscles involved, as listed in the following table.

Table 1: Characteristics of Movement, Physical Elements and Major Muscles Involved

\begin{tabular}{|c|c|c|c|}
\hline Movement & Characteristics of Movement & $\begin{array}{l}\text { Physical } \\
\text { Element }\end{array}$ & $\begin{array}{l}\text { Major } \\
\text { Muscles } \\
\text { Involved }\end{array}$ \\
\hline Kick & $\begin{array}{l}\text { - Hard kick, strong and fast } \\
\text { - Coordinate movement }\end{array}$ & $\begin{array}{l}\text {-speed } \\
\text {-strength } \\
\text {-shape }\end{array}$ & \multirow{4}{*}{$\begin{array}{l}\text { - Shoulders } \\
\text { - upper arm } \\
\text { - forearm } \\
\text { - back } \\
\text { - chest } \\
\text { - stomach } \\
\text { - waist } \\
\text { - limbs } \\
\text { - ankle }\end{array}$} \\
\hline Blows & $\begin{array}{l}\text { - hard blows, strong and fast } \\
\text { movement } \\
\text { - Coordination - Speed }\end{array}$ & $\begin{array}{l}\text {-Speed } \\
\text {-Accuracy } \\
\text { - Agility } \\
\text { - accuracy }\end{array}$ & \\
\hline Avoid & $\begin{array}{l}\text { - fast evasion } \\
\text { - Fast evasion } \\
\text { - Meticulous } \\
\text { - Movement } \\
\text { - Movemen Coordination }\end{array}$ & $\begin{array}{l}\text {-Speed } \\
\text {-Accuracy } \\
\text { - Agility } \\
\text { - accuracy }\end{array}$ & \\
\hline Denial & $\begin{array}{l}\text { - quick denial } \\
\text { - fast reaction } \\
\text {-motion coordination } \\
\text { - Rapid reaction } \\
\text { - carefulness of motion } \\
\text { - motion coordination }\end{array}$ & $\begin{array}{l}\text {-Speed } \\
\text {-Accuracy } \\
\text { - Agility } \\
\text { - accuracy }\end{array}$ & \\
\hline
\end{tabular}

Prediction The need of physical quality in the sport of martial art, among others:

a. Power and anaerobic capacity are visible on kicks, punches, denials shadows, drops, dings.

b. Endurance of strength on the number of kicks, punches, evasion tanks.

c. Cardiorespiratory endurance at the length of time each round and overall

d. Agility and accuracy on the avoid kick, avoid the beating, denials, catch the fall.

e. The formation of high-defense attack movement.

f. Coordinate on the whole attack movement. 


\section{International Journal of Science and Research (IJSR) \\ ISSN (Online): 2319-7064}

Index Copernicus Value (2015): 78.96 | Impact Factor (2015): 6.391

\section{Research Methodology}

\section{A. The Objectives of research}

Based on the background, problem identification, and problem formulation that has been previously disclosed, the purpose of this research is as follows:

1) Knowing which anthropometry factors are dominant determines the quality of the physical condition of martial arts martial arts categories for juvenile athletes.

2) Knowing which anthropometry factors predominantly determine the quality of physical condition of martial arts martial category for female teenage athletes.

3) To know which factors of physical condition predominantly determine the quality of physical condition of martial arts martial category for male teen athletes.

4) Knowing which physical condition factors predominantly determine the quality of physical condition of martial arts martial category for female teenage athletes.

5) To know the relationship between dominant anthropometry factor and the achievement of martial arts athlete category of teenage boys.

6) To know the correlation between dominant anthropometry factor and the achievement of martial arts athlete category of female teenagers.

7) Knowing the relationship between dominant physical condition factors with the achievement of martial arts athlete category of teenage boys.

8) To know the correlation between dominant physical condition factor and the achievement of martial arts athlete category of female teenagers.

9) Knowing the relationship between dominant anthropometry factor and dominant physical condition factor simultaneously with the achievement of martial arts athlete category of young men.

10) Knowing the relationship between dominant anthropometry factor and dominant physical condition factor simultaneously with the achievement of martial arts athlete category of female teenagers.

\section{B. Research Approach and Data Analysis Technique}

This research was a quantitative research using survey method. Based on the level of explanation, this study is categorized correlational research in which research conducted to determine the relationship between variables hypothesized in the study.

After taking the data in the form of anthropometry measurement which consist of weight, height, length of arm range, sitting height, leg length and foot length, and test result and measurement of physical condition component consisting of several physical components with data analysis used in this research was factor analysis.

Factor analysis is a technique to analyze the interdependence of several variables simultaneously with the aim to simplify the form of the relationship between several variables studied to a number of factors less than the variables studied. The steps in the factor analysis are as follows: (a) Formulating the problem; (B) Creating a correlation matrix; (C) Determination of the number of factors; (D) factor
Rotation; (E) Interpretation of factors; (F) Selection of surrogate variables; And (g) Fit Model (model accuracy).

\section{Result and Discussion}

\section{A. Description of Research Data}

\begin{tabular}{|c|c|c|c|c|}
\hline \multirow[t]{2}{*}{ Statistic } & \multicolumn{2}{|c|}{ Mean } & \multicolumn{2}{|c|}{$\begin{array}{c}\text { Std. } \\
\text { Deviation) }\end{array}$} \\
\hline & $\mathrm{N}$ & Womer & Men & Women \\
\hline Weight $(\mathrm{X} 1)$ & 56.87 & 50.38 & 90.15 & 7.02 \\
\hline$\overline{\text { Height (X2) }}$ & 166.72 & 155.54 & 53.40 & 6.33 \\
\hline Arm Range Length (X3) & 167.99 & 155.65 & 82.61 & 6.92 \\
\hline Sitting Height (X4) & 87.36 & 83.66 & 20.81 & 6.21 \\
\hline Length (X5) & 90.75 & 87.80 & 145.81 & 9.22 \\
\hline Footprint Length (X6) & 24.49 & 23.24 & 12.54 & 1.07 \\
\hline Sit And Reac (X7) & 18.84 & 18.07 & 29.34 & 5.49 \\
\hline Shoulder Flexibility T & 37.14 & 36.95 & 93.62 & 10.97 \\
\hline Ruller Drop Test (X9) & 19.14 & 20.82 & 26.02 & 6.22 \\
\hline $\begin{array}{l}\text { Eye, Hand and Foot } \\
\text { Coordination (X10) }\end{array}$ & .96 & 15.58 & $52.9^{\prime}$ & 4.91 \\
\hline Balance (X11) & 34.82 & 24.91 & 606.85 & 10.86 \\
\hline Triple Hop Jump (X12) & 12.22 & 9.28 & 1.17 & 1.63 \\
\hline Basketball Throw (X13) & 6.49 & 5.27 & 1.24 & 2.18 \\
\hline Hexogon Obstacle Test (X14) & 13.52 & 15.33 & 8.32 & 3.73 \\
\hline Jump Drop (X15) & 18.67 & 13.41 & 20.35 & 4.80 \\
\hline Hand Speed (X16) & 50.69 & 42.86 & 122.03 & 10.01 \\
\hline Run 3 Meters (X17) & 7.52 & 7.88 & 2.11 & 0.94 \\
\hline Run 30 Meters (X18) & 4.78 & 5.55 & 0.14 & 0.39 \\
\hline Handgrip Strengh (X19) & 35.55 & 23.36 & 63.79 & 5.49 \\
\hline Push Up (X20) & 45.56 & 39.63 & 176.84 & 10.76 \\
\hline Sit Un $(\mathrm{X} 2$ & 50.92 & 41.11 & 116.42 & 11.83 \\
\hline Back Up (X22) & 84.37 & 68.23 & 413.77 & 18.65 \\
\hline Leg squat (x23) & 31.47 & 13.93 & 62.88 & 7.57 \\
\hline Multi Phase Run (X24) & 48.44 & 36.25 & 62.76 & 6.99 \\
\hline
\end{tabular}

\section{B. Normality Test Data}

\begin{tabular}{|c|c|c|c|c|c|c|}
\hline \multirow{2}{*}{ Statistic } & \multirow{2}{*}{$\mathrm{N}$} & \multicolumn{2}{|c|}{ Men } & \multicolumn{2}{|c|}{ Women } & \multirow{2}{*}{ Note } \\
\hline & & L_count & Sig. & L_count & Sig. & \\
\hline Weight (X1) & & .062 & $.200^{*}$ & .061 & $.200^{*}$ & \\
\hline Height ( & & 079 & .125 & .091 & .041 & \\
\hline arm range length (X3) & & .069 & $.200^{*}$ & .106 & .008 & \\
\hline Sitting height (X4) & & .074 & .196 & .253 & .000 & \\
\hline Length (X5) & & .232 & .000 & .222 & .000 & \\
\hline Footprint length (X6) & & .325 & .000 & .190 & .000 & \\
\hline Sit $\mathrm{Al}_{2}$ & & .085 & .070 & .085 & .070 & \\
\hline $\begin{array}{c}\text { Shoulder Flexibility Test } \\
\text { (X8) }\end{array}$ & & .082 & .092 & .130 & .000 & \\
\hline Ruller Drop Test (X9) & & .108 & .006 & .072 & $.200^{*}$ & \\
\hline $\begin{array}{l}\text { Eye, Hand and Foot } \\
\text { Coordination (X10) }\end{array}$ & & .138 & .000 & .110 & .004 & 票票 \\
\hline Balance (X11) & & 108 & .006 & 177 & .000 & \\
\hline Triple Hop Jump (X12) & & .065 & $.200^{*}$ & .076 & .168 & $\because$ \\
\hline Basketball Throw (X13) & & .129 & .000 & 188 & .000 & 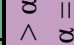 \\
\hline $\begin{array}{c}\text { Hexagon Obstacle Test } \\
\text { (X14) }\end{array}$ & & 093 & .032 & .108 & .006 & $\frac{.00}{0.0}$ \\
\hline Jump Drop (X15) & & .079 & .125 & .156 & .000 & \\
\hline Hand $S$ & & .055 & $.200^{*}$ & .100 & .015 & \\
\hline Lari Bolak Balik 3 Mete & & .107 & .007 & .088 & .053 & \\
\hline
\end{tabular}


International Journal of Science and Research (IJSR)

ISSN (Online): 2319-7064

Index Copernicus Value (2015): 78.96 | Impact Factor (2015): 6.391

\begin{tabular}{|c|c|c|c|c|}
\hline (X17) & & & & \\
\hline Run to 3 Meters (X18) & .081 & .108 & .044 & $.200^{\prime}$ \\
\hline Handgrip Strengh (X19) & .057 & $.200^{*}$ & .093 & .031 \\
\hline Push Up (X20) & .077 & .153 & .077 & .148 \\
\hline Sit Up (X21) & .067 & $.200^{3}$ & .050 & .200 \\
\hline Back Up (X22) & .065 & $.200^{\prime \prime}$ & .069 & $.200^{\prime}$ \\
\hline Leg Squat (X23) & .078 & .137 & .199 & .000 \\
\hline Multi-Phase Run (X24) & .058 & .200 & .116 & .002 \\
\hline
\end{tabular}

C. Result of Analysis Confirmatory Factor Step I

\begin{tabular}{|c|c|c|c|c|}
\hline \multirow[t]{2}{*}{ Statistik } & \multirow[t]{2}{*}{$\mathrm{N}$} & \multicolumn{2}{|c|}{$\begin{array}{l}\text { Analisis } \\
\text { Tahap I } \\
\end{array}$} & \multirow[t]{2}{*}{ Ket. } \\
\hline & & Putra & Putri & \\
\hline Weight (X1) & & 0.799 & 0.640 & 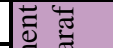 \\
\hline Height (X2) & & 0.773 & 0.682 & \\
\hline Long arm range (X3) & & 0.648 & 0.671 & ] \\
\hline Sitting high (X4) & & 0.723 & 0.639 & $\bar{\pi}$ \\
\hline Long legs (X5) & & 0.579 & 0.639 & 可 \\
\hline Foot length (X6) & & 0.451 & 0.331 & กิ: \\
\hline Sit And Reac (X7) & & 0.402 & 0.452 & 0 \\
\hline Shoulder Flexibility Test (X8) & & 0.539 & 0.657 & $\sqrt{\sqrt{\pi}}$ \\
\hline Ruller Drop Test (X9) & & 0.367 & 0.459 & \\
\hline $\begin{array}{l}\text { Eyes, hand, and foot coordination } \\
\text { (X10) }\end{array}$ & & 0.613 & 0.632 & \\
\hline Balance (X11) & & 0.223 & 0.419 & \\
\hline Triple Hop Jump (X12) & 100 & 0.801 & 0,838 & \\
\hline Throwing basketball (X13) & & 0,736 & 0.640 & 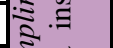 \\
\hline Hexagon Obstacle Test (X14) & & 0.831 & 0.741 & 旅 \\
\hline Jump Drop (X15) & & 0.712 & 0.665 & \\
\hline Hand speed (X16) & & 0.544 & 0.598 & \\
\hline run back and forth 3 meters (X17) & & 0.729 & 0.782 & \\
\hline Run to 30 Meters (X18) & & 0.587 & 0.734 & 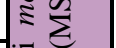 \\
\hline Handgrip Strengh (X19) & & 0.753 & 0.593 & \\
\hline Push Up (X20) & & 0,810 & 0.738 & \\
\hline Sit Up (X21) & & 0,747 & 0.800 & 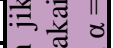 \\
\hline Back Up (X22) & & 0,715 & 0.778 & \\
\hline Leg Squat (X23) & & 0.650 & 0.779 & छ है \\
\hline Multi-Phase Run (X24) & & 0.769 & 0,812 & \\
\hline
\end{tabular}

In the Anti Image Matrices correlation tab, there are four variables that have MSA value under 0,50 was the foot length (x6), sit and reach (X7) ruller drop test (X9) and balance (X11) athletes men and women respectively $(0.451$, $0.492,0.367$ and 0.223$)$ and $(0.331,0.452,0.459$ and 0.419$)$, which had to be redisplayed and must be removed or eliminated as they were not significant for further tests.

The next step was to reduce the variable with factor analysis II by not including the anthropometric variable for the foot length indicator because in the first analysis step both had MSA value below 0.5 which means that factor is not eligible to be included in factor analysis II.

\section{Result of Analysis Confirmatory Factor Step II}

\begin{tabular}{|c|c|c|c|}
\hline \multirow[t]{2}{*}{ Statistics } & \multirow[t]{2}{*}{$\mathrm{N}$} & $\begin{array}{c}\text { Analysis } \\
\text { step I }\end{array}$ & \multirow[t]{2}{*}{ Ket. } \\
\hline & & \begin{tabular}{|l|} 
Putra Putri \\
\end{tabular} & \\
\hline Weight (X1) & & $0,6610,661$ & $\dot{\infty}$ \\
\hline Height (X2) & & \begin{tabular}{|l|l|l|}
0,682 & 0,682 \\
\end{tabular} & no \\
\hline Long arm range (X3) & & $0,668 \mid 0,668$ & \\
\hline Sitting high (X4) & & $0,674 \mid 0,674$ & \\
\hline Long legs (X5) & & \begin{tabular}{|l|l|}
0,679 & 0,679 \\
\end{tabular} & \\
\hline Foot length (X6) & & $, 7090,709$ & \\
\hline Sit And Reac (X7) & & $0,6630,663$ & \\
\hline Shoulder Flexibility Test (X8) & & $0,6640,664$ & 造 \\
\hline Ruller Drop Test (X9) & & $0,8430,843$ & $=0$ \\
\hline Eyes, hand, and foot coordination (X10) & & $0,6770,667$ & 20 \\
\hline Balance (X11) & & $0,7750,775$ & है ? \\
\hline Triple Hop Jump (X12) & & \begin{tabular}{|l|l|}
0,693 & 0,693 \\
\end{tabular} & 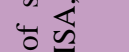 \\
\hline Basketball throw (X13) & & $0,674 \mid 0,674$ & $\sum$ \\
\hline Hexagon Obstacle Test (X14) & & $0,7830,783$ & \\
\hline Jump Drop (X15) & & $0,7880,788$ & $\tilde{g}^{2}$ \\
\hline Hand speed (X16) & & \begin{tabular}{|l|l|}
0,584 & 0,584 \\
\end{tabular} & 40 \\
\hline Run 3 Meters (X17) & & $0,735 \mid 0,735$ & 5 \\
\hline Run 30 Meters (X18) & & $0,8000,800$ & \\
\hline Handgrip Strengh (X19) & & \begin{tabular}{|l|l|}
0,793 & 0,793 \\
\end{tabular} & $\because \overline{3}$ \\
\hline Push Up (X20) & & $0,8280,828$ & $=\pi$ \\
\hline Sit Up (X21) & & \begin{tabular}{|l|l|}
0,661 & 0,661 \\
\end{tabular} & \\
\hline Back Up (X22) & & $0,6820,682$ & \\
\hline Leg Squat (X23) & & $0,6680,668$ & 吾吾 \\
\hline Multi phase run (X24) & & $0,674 \mid 0,674$ & \\
\hline
\end{tabular}

In Anti Image Matrices tabulation there was no variable that had MSA value under0,50 which means that all variables can be tested further using extraction process with Principal Component Analysis method that yield value of Communalities.

\section{E. Result of Extraction Steps}

\begin{tabular}{|c|c|c|c|c|}
\hline \multirow[t]{2}{*}{ Statistic } & \multirow[t]{2}{*}{$\mathrm{N}$} & \multicolumn{2}{|c|}{\begin{tabular}{|c|} 
Analysis Steps Ii \\
extraction step \\
\end{tabular}} & \multirow[t]{2}{*}{ Note } \\
\hline & & Men & Women & \\
\hline Weight (X1) & \multirow{20}{*}{100} & 0.674 & 0.559 & \\
\hline Height (X2) & & 0.730 & 0.809 & \\
\hline Arm Range Length (X3) & & 0.756 & 0.803 & \\
\hline Sitting Height (X4) & & 0.589 & 0.712 & \\
\hline Length (X5) & & 0.514 & 0.609 & 8 \\
\hline shoulder flexibility test (X8) & & 0.628 & 0.509 & 8 \\
\hline $\begin{array}{c}\text { koordinasi mata, tangan dan kaki } \\
(\mathrm{X} 10)\end{array}$ & & 0.586 & 0.602 & 을 \\
\hline triple hop jump (X12) & & 0.544 & 0.604 & \\
\hline lempar bola basket (X13) & & 0.558 & 0.523 & $\underset{0}{0}$ \\
\hline hexagon obstacle test (X14) & & 0.613 & 0.582 & . \\
\hline Jump Drop (X15) & & 0.686 & 0.634 & $\overparen{E}$ \\
\hline Hand speed (X16) & & 0.680 & 0.554 & $\underset{0}{a}$ \\
\hline Run 3 meter (X17) & & 0.483 & 0.711 & $\overline{\mathscr{Z}}$ \\
\hline Run 30 meter (X18) & & 0.592 & 0.494 & 4 \\
\hline handgrip strengh (X19) & & 0.656 & 0.731 & $\vec{z}$ \\
\hline push up (X20) & & 0.605 & 0.637 & $\stackrel{0}{2}$ \\
\hline sit up (X21) & & 0.630 & 0.739 & \\
\hline back up (X22) & & 0.501 & 0.618 & \\
\hline Leg squat (X23) & & 0.509 & 0.677 & \\
\hline Multi Phase Run (X24) & & 0.737 & 0.653 & \\
\hline
\end{tabular}

\section{Volume 6 Issue 7, July 2017} www.ijsr.net 


\section{International Journal of Science and Research (IJSR) \\ ISSN (Online): 2319-7064}

Index Copernicus Value (2015): 78.96 | Impact Factor (2015): 6.391

\section{Conclusion}

Based on the results of research and data analysis that has been done, and refer to the discussion in the previous chapter, it turns out the proposed hypothesis can be accepted, so it can be concluded that the anthropometry factor and physical condition condition (latent variables $\xi 1$ and latent variables $\xi 2$ ) that determine the physical quality of the athlete Pencaksilat category of matches of young men and women can be measured from each research indicator as follows:

1) The dominant factor of anthropometry determines the physical quality of the athlete of the male teenage counter category comprising X1 weight $(0.674$ or $67.4 \%)$, height of X2 $(0.730$ or $73 \%)$, length of X3 arm bands $(0.756$ or $75,6 \%), \mathrm{X} 4$ seated height $(0.589$ or $58.9 \%)$ and limb length X5 (0.514 or $51.4 \%)$.

2) The dominant factor of anthropometry determines the physical quality of martial arts athletes in the category of female teenagers consisting of X1 weight $(0,559$ or $55,9 \%)$, height $\mathrm{X} 2(0,809$ or $80,9 \%), 0.803$ or $80.3 \%)$, $\mathrm{X} 4$ seated height $(0,712$ or $71,12 \%)$ and length of limb X5 $(0,609$ or $60,9 \%)$

3) The dominant factor of the quality of physical condition determines the physical quality of the athlete of the male teenage match category consisting of: shoulder flexibility test X8 $(0,628$ or $62,8 \%)$, eye coordination, hand and foot X10 equal to 0,586 or $58,6 \%$ Triple hop jump X12 $(0,544$ or $54,4 \%)$, X13 basketball throw $(0,558$ or $55,8 \%)$, hexogon obstacle test X14 $(0,613$ or $61,3 \%)$, X15 jump height $(0,686$ or $68,6 \%)$, hand velocity X16 $(0.680$ or $68.0 \%)$, sprint 3 meters X17 $(0.483$ or $48.3 \%)$, run 30 meters X18 $(0,592$ or $59,2 \%)$, handgrip strength X19 $(0,656$ or $65,6 \%)$, push up X20 $(0,605$ or $60,5 \%)$, sit up X21 $(0,630$ or $63,0 \%)$, back up X22 $(0,501$ or $50,1 \%)$, X23 multiracial races $(0.509$ or $50.9 \%)$, and one leg squat X24 (0.737 or $73.7 \%)$.

4) The dominant factor of the quality of physical condition determines the physical quality of the athlete of the category of female teenagers consisting of: shoulder flexibility test X8 $(0,509$ or $62,5 \%)$, eye coordination, hands and feet X10 $(0,602$ or $60,2 \%)$, Triple hop jump $\mathrm{X} 12$ for $(0,604$ or $60,4 \%), \mathrm{X} 13$ basketball throwing $(0,523$ or $52,3 \%)$, hexogon obstacle test X14 equal $(0,582$ or $58,2 \%)$, X15 agility jump $(0,634$ or $63,4 \%)$, hand velocity X16 $(0,554$ or $55,4 \%)$, sprint 3 meter X17 $(0,711$ or $71,1 \%), 30$ meter X18 $(0,494$ or $49,4 \%)$, handgrip strength X19 $(0,731$ or $73,1 \%)$, push up X20 $(0,637$ or $63,7 \%)$, sit up X21 $(0,739$ or $73,9 \%)$, back up X22 $(0,618$ or $61,8 \%)$, The X23 multiracial run $(0.677$ or $67.7 \%)$, and one leg squat X24 (0.653 or $65.3 \%)$.

5) There was a correlation between anthropometry factor with achievement of male teenagers in martial art of equal to 0.61

6) There was a correlation between anthropometry factor with the achievement of juvenile athlete martial art category equal to 0,695

7) There was relationship between physical condition factor with achievement of athlete of martial art category of teen men equal to 0,816

8) There was correlation between physical condition factor with achievement of juvenile athlete martial art at men equal to 0,762
9) There was a relationship between anthropometry factor and physical condition factor simultaneously with the achievement of teenagers athletes martial art men's category equal to 0.844

10) There was an association between anthropometry factor and physical condition factor simultaneously with the achievement of juvenile athlete martial art category equal to 0.829 .

\section{References}

[1] Harsono. Coaching dan Aspek-aspek Psikologi. Jakarta, CV Tambak Kusuma, 1988.

[2] PB IPSI, Peraturan Pertandingan Ikatan Pencak SIlat Indonesia Munas IPSI 2012. Jakarta: PB IPSI, 2012.

[3] Pheasant, S. Body Space. Anthropometry, Ergonomics and Design. London: Taylor \& Francis, 1988.

[4] Pulat, B.M. Fundamentals of Industrial Ergonomics. New Jersey USA: Hall International. Englewood Cliffs, 1992.

[5] Sajoto, M. Pembinaan Kondisi Fisik Dalam Olahraga. Jakarta: Depdikbud, 1988.

[6] Sanders, Mark S. dan McCormick, Ernest J. Human Factors in Engineering and Design, $6^{\text {th }}$. England: Mcgraw-Hill Book Company, 1987.

[7] Sugiyanto. Belajar Gerak. Surakarta: UNS Press, 1993.

[8] Tarwaka, Bakri, Solichul H.A., Sudiajeng, Lilik. Ergonomi untuk Keselamatan, Kesehatan Kerja dan Produktivitas, Edisi I, Cetakan I. Surakarta: UNIBA PRESS, 2004.

[9] Wickens, C.D., Lee, J.D., Liu, Y. Gorden Becker S.E. An Introduction to Human Factors Engineering $2^{\text {nd }}$ Edition. London: Pearson Education Inc., 2004. 